\title{
EXAMINATION OF THE TREND OF RENTAL VALUES OF BUNGALOWS IN SELECTED AREAS OF BENIN CITY
}

\author{
${ }^{1}$ Raphael Oshiobugie Sado, ${ }^{2}$ Ifeanyichukwu Valentine Nwafor, Stanley Chika Nwaogu ${ }^{3}$ \\ ${ }^{1}$ Department of Estate Management, Nnamdi Azikiwe University, Awka \\ ${ }^{2}$ Department of Estate Management, University of Nigeria \\ ${ }^{3}$ Department of Estate Management, University of Nigeria
}

\begin{abstract}
Citation: Raphael Oshiobugie Sado, Ifeanyichukwu Valentine Nwafor, Stanley Chika Nwaogu(2022)Examination of the Trend of Rental Values of Bungalows in Selected Areas of Benin City, European Journal of Accounting, Auditing and Finance Research,Vol.10, No. 2, pp.64-75
\end{abstract}

\begin{abstract}
ASTRACT: Bungalows are types of residential properties that provide a detached single unit of accommodation basically for family units and provide rental value returns to investors who develop them. However, studying the trend of rental values from such investments is of concern to the investors as it would help them appreciate its viability. The aim of this study is to analyze the trend of rental values of Bungalows in selected areas of Benin City comprising; GRA, Sapele road, Airport road, Ekenwan, Siluko, Ugbowo, Sakponba road, Ikpoba Hill and Aduwawa, in order to determine the growth model and statistical significance of their variations within each area between 2011 and 2020. The research methodology employed was the survey research design. Responses were retrieved from Estate Surveying and Valuation Firms involved in property management in Benin. Data retrieved were analyzed using Tables, Graph, Trend analysis and One-way ANOVA. The study revealed that the trend of rental values of Bungalows indicates a steady increase over a period of time and that there is significant variation of rental values of Bungalows in the selected locations. It was therefore concluded that the trends and variations could be attributed to the size of the property, facilities available, neighbourhood characteristics, etc, and recommended that intending investors should consider such factors before delving into investing in Bungalow residential property investment in Benin City in order to enjoy maximum rental return.
\end{abstract}

KEYWORDS: trend, rental values, bungalows, areas, Benin City.

\section{INTRODUCTION}

Housing which is best defined as residential property is a necessity for the survival of man as it is one of the basic needs of man besides food and clothing. However, there is a cost to be paid for the acquisition of such commodity either for permanent occupation or ownership (out-right purchase) or for temporal occupation and possession (under a lease or tenancy). For the latter to come into being there is a consideration amongst other factors such as terms of lease (tenancy), period covered, that must be agreed upon by the parties involved and settled by the lessee (tenant) termed "Rental value". Rent was defined by Egolum (2002) as the periodic payment made by a tenant to the landlord in consideration for use and occupation of his land or land and building, and Kuye (2003) established rent to mean the payment for the use of another person's property. Rental value of a property according to Egolum is the rent at which the property would be let at a given date if the property were put out in the market with adequate advertisement and time to attract prospective tenants who are abreast of the property market situations and the potentials of the subject property. 
Ratcliff (1978) as cited in Ekenta (2015) stated that "historically rent was used to refer to any periodic payment to a landlord for the use of property or land. The concept of rent is variously defined by different professionals such as economists, business administrators and estate surveyors and valuers to include; contract rent, economic rent and market rent. For the sake of this study, focus is on contract rent which is defined by The Nigeria Valuation Standards (2019) as the rent payable under the terms of an actual lease, it is the rent agreed upon by a willing landlord and tenant under a lease or tenancy agreement. Contract rent may be fixed for the duration of the lease or variable.

Residential properties are both consumption and investment goods (Ekenta, 2015). The demand for residential properties is generally on the increase as the population grows and Benin City is not left out with a population of 1,727,000 and growth rate of 3.04\% in 2020 from a population of 1,334,000 and growth rate of $2.93 \%$ in 201 respecti9vely (United Nation's (UN) - World Population Prospects, 2021); reflecting the gap in population between the period of this study, and this has led to increase in demand for accommodation in form of residential properties with no coherent means to meet up thereby resulting in increase in rental values which can be reflected in a trend over the period.

This study is therefore aimed at analyzing the trend of rental values of residential property investment with focus on Bungalows in selected areas of Benin City comprising; GRA, Sapele road, Airport road, Ekenwan, Siluko, Ugbowo, Sakponba road, Ikpoba Hill and Aduwawa, in order to determine the growth model and statistical significance of the variation of rental values within each area between 2011 and 2020.

To achieve the above aim, the objectives of this research include:

-To assess the rental values of Bungalow Properties in the selected areas within Benin City over the period of 2011 to 2020 ;

-To ascertain the trend model of rental values of Bungalows in the selected areas over the study period;

In order to achieve the objectives, the study sampled Bungalows of similar physical features and design in all the nine selected areas of the study

\section{LITERATURE REVIEW}

\section{Concept of Property}

Property according to Udechukwu (2006) is a legal concept encompassing all the interest, rights and benefits related to ownership It consists of the rights of ownership, which entitles the owner to a specific interest or interests in what is a physical entity and its ownership. The ownership of real estate is called real property while the combination of rights associated with the ownership of real property is in some states, referred to as the bundle of rights. The Nigeria Valuation Standards (2019) defined real property interest as stated in the International Valuation Standards (IVS 400 in paragraph 20.2) as a right of ownership, control, use or occupation of land and buildings, and defined real estate as a property to comprise land and all things that are natural part of the land; for example; trees, minerals and things that have been attached to the land like buildings and site improvements, and all permanent building attachments like mechanical and electrical plants providing services to the building, that are both below and above the ground. 


\section{Concept of Residential Properties}

According to Kuye (2011), Residential properties are properties meant for dwelling purposes either by an individual or corporate body. This could be in form of block of flats, detached houses, duplexes, terrace buildings, or tenement buildings. Ogunba (2013) further stated that housing is the largest use of land in the urban areas and that it is generally forced out of central areas by the expansion of business uses. Only high income housing and local authority housing (like in the UK, etc) are not forced out. Residential property users have to balance accessibility requirement with those of amenity.

\section{Types of Residential Properties}

Emoh (2004) also stated that residential properties are buildings that are suitable for living and they appear in various forms as follows;

a) Tenement Building: - These are buildings made up of detached rooms with a common corridor.

b) Block of Flats: - These consists of two, three, four or more bedrooms with a sitting room, toilets, bathrooms and kitchen with food store in some cases for the exclusive use of the occupier.

c) Bungalow: - This is a self-contained building for single family on a ground floor only.

d) Duplex: -This is a semidetached building with a common wall partition separating it from another.

e) Masonette: - These are owner occupied houses under one single family occupation with all the bedrooms en-suite.

\section{Bungalows as a Type of Residential Property}

According to Kuye (2009) this is a building directly and only on ground floor or single floor; it accommodates a single family unit and is usually self-contained i.e. having all necessary facilities and utilities. They are also referred to as private houses/homes. Bungalows may be in detached or semidetached form having two sections and one being the mirror image of the other, and they could be of any sizes.

\section{Concept of Rental Value}

Udechukwu (2006) defined rental value as the worth of lease of property on a periodic basis. When the sum is similar to what any similar property would attract, such rent is called market rent, $\mathrm{i}$ e the rental value, therefore is the worth of the property on periodic occupational basis. It is the rent such property, or a similar one, would attract when offered in the market on the usual tenancy or lease terms and conditions characterizing the market of such class and type of property.

The Nigeria Valuation Standards (2019) defined the concept of market rent as the estimated amount for which an interest in real property should be leased on the valuation date between a willing lessor and willing lessee on appropriate lease terms in an arm's length transaction, after proper marketing and where the parties had each acted knowledgeably, prudently, and without compulsion. It was further stated that market rent may be used as a basis of value when valuing a lease or an interest created by a lease. In such cases, it is necessary to consider the contract rent and, where it is different, the market rent. The appropriate lease terms will normally reflect current practice in the market in which the property is situated. It will normally be used to indicate the amount for which a vacant property may be let, or for which a let property may be re-let when the existing lease terminates. Thus focus is on contract rent as stated earlier defined by The Nigeria Valuation Standards (2019) as the rent payable under the terms of an actual lease; rent agreed between a lessor and lessee, and actually being paid. 


\section{Determinants of the Rental Value of Residential Properties}

According to Udechukwu (2006), when residential properties are available for rent, it is considered a good investment. The rental value is dependent on the condition, location and neighbourhood of the premises, and the availability of services such as lifts, water, electricity, etc. However, Journal of Housing Economics (1996) as cited in Udechukwu explained the features of residential properties that determine their values as follows;

\section{Size of land and structure}

One of the basic features of residential property is the specific size of the land and the structure, itself. It is obvious that a four bedroom, two-bath house is likely to be more valuable than a two-bedroom, one-bath house in the same location. The area of land the house occupies can make a drastic difference in the price the property will bring. People tend to prefer large land and personal space to houses that are crammed together on tiny lots

\section{Condition}

The condition of a house will make a significant impact on the property value of a residential property. For instance, a house in disrepair with a leaky roof, or out of date style is likely to command less value than the same house in a good condition or that is more modern to a would -be inhabitant.

\section{Extras}

The extras associated with a residence such as, a garage, a pool and other non-essential houses, if available will seriously affect the value a person is likely to ascribe to it positively, thus a higher price may be warranted from buyers seeking such extras.

\section{Public opinion}

One of the most powerful factors affecting the value of a residence is the opinion of the locals. This feature relates to the opinion of the neighborhood or towns' reputation and this will drastically improve or reduce the potential for a good offer perception is reality in the Real Estate game.

\section{Convenience}

A residential property if closer to a grocery store or hospital, will command a higher residential value than that farther from such. However, a quiet neighbourhood residential property even though a little farther may still command a reasonable value.

\section{Curb appeal}

This reflects the look of the house from the outside, potential buyers who drives by a particular attractive building may fall in love with a new home before they even set foot inside. This powerful first impression can lead to a higher offer

\section{Neighbourhood values}

When homes around you sell, the selling price of other homes in the neighbourhood is taken into consideration when an appraisal is needed. If other houses in the neighbourhood have sold for an average $\$ 50,000$, it is highly likely that you will be able to get $\$ 45,000$, unless it is far more impressive than anything else in the area. 


\section{Government laws}

Government laws with respect to residential properties are far more stringent and can override anything that you may have written in the sales or rental agreement during transactions with the property. These protections are put in place so that residential buyers and tenants are not exploited. As for tenants, in some countries and states the laws are so much in their favour that you cannot evict them even in cases where they are behind on their rents.

\section{Property management cost}

Residential property management takes time and effort because you deal with people. Once you have several residential investments, it can become a full time job Residential property managers charge anywhere from $5 \%-10 \%$ on the rent collected towards the management fee.

\section{Vacancy rate}

The biggest advantage of a residential property is that it is fairly easy to find a new tenant once your property becomes vacant. This reduces the vacancy rate, thus continuous cash flow coming from the investment. The only reason for long time vacancy is if your rents are high for the location at the particular time, but if rent is dropped to a reasonable value, you will normally find a tenant. This is because people have to live anywhere at an affordable cost.

\section{RESEARCH METHODOLOGY}

The study adopted the survey research design which involves collecting samples from a specific group of individuals in order to describe and explore the behaviour of such data, frequently used in social and psychological research (Singleton \& Straits, 2009). Data were obtained from income (rental values) from Bungalow residential properties in the selected areas from the Registered and practicing Estate Surveying and Valuation firms in Benin between 2011 and 2020. The instruments of Questionnaires, direct oral interview and observation of documented records were adopted in retrieving relevant data from the firms, which were presented using tables and analyzed using Trend analysis; being a method that captures the average path which data follows over time in a Time series graph, displaying the general trend of movement despite seasonal or cyclical variation over a length of time (Omotoso, 2002), and Oneway Analysis of Variance (ANOVA) with $p \leq 0.05$ level of confidence adopted as decision rule to indicate if there is a significant variation among the mean scores on the dependent variable (Pallant, 2011).

\section{MATERIALS AND DISCUSSION}

The study sought to examine the Trend of Rental Values of Bungalows in selected areas of Benin City. Responses retrieved through research instruments employed are presented and analyzed a s follows:

\section{The Rental Values of Bungalow Residential Properties in Selected Areas within Benin over the Period of 2011 to 2020}

Table 1 presents the rental values of Bungalows in the selected areas comprising: GRA, Sapele road, Airport road, Ekenwan, Siluko, Ugbowo, Sakponba road, Ikpoba Hill and Aduwawa, generated from Estate Surveying and Valuation Firms in Benin City as follows: 
Print ISSN: 2053-4086(Print),

Online ISSN: 2053-4094(Online)

Table 1: The average Rental Values of Bungalows per annum within Selected Areas in Benin City between 2011 and 2020

\begin{tabular}{|c|c|c|c|c|}
\hline Year & $2011-2013$ & $2014-2016$ & $2017-2019$ & 2020 \\
\hline $\begin{array}{l}\text { Residential location } \\
\text { (Bungalow - detached house) }\end{array}$ & $\begin{array}{l}\text { Rental value } \\
(\mathbf{N}, \mathbf{0 0 0})\end{array}$ & $\begin{array}{l}\text { Rental value } \\
(\mathbf{N , 0 0 0 )}\end{array}$ & $\begin{array}{l}\text { Rental value } \\
(\mathbf{N , 0 0 0 )}\end{array}$ & $\begin{array}{l}\text { Rental value } \\
\text { (\$,000) }\end{array}$ \\
\hline GRA & 388 & 450 & 525 & 640 \\
\hline Sapele road & 300 & 375 & 420 & 500 \\
\hline Airport road & 378 & 438 & 478 & 575 \\
\hline Ekenwan & 187 & 238 & 275 & 308 \\
\hline Siluko & 150 & 200 & 240 & 270 \\
\hline Ugbowo & 150 & 208 & 260 & 300 \\
\hline Sakponba road & 200 & 240 & 270 & 290 \\
\hline Ikpoba Hill & 170 & 200 & 233 & 267 \\
\hline Aduwawa & 167 & 203 & 240 & 270 \\
\hline
\end{tabular}

From Table 1 above, it is observed that rental values have generally increased for Bungalows over the study period of 2011 to 2020 in all the selected areas, however, GRA indicated the highest averages of $\$ 388,000$ in 2011 to 2013, $\$ 450,000$ in 2014 to 2016, $\$ 525,000$ in 2017 to 2019 and $\$ 640,000$ in 2020. This is followed by Airport road and Sapele road, then Ekenwan, Sakponba road and Ugbowo, while the lowest are indicated in Aduwawa, Siluko and Ikpoba Hill, with the lowest in 2011 to 2013 indicated in Ugbowo and Siluko respectively at $\$ 150,000,2014$ to 2016 in Siluko and Ikpoba Hill respectively at $\$ 200,000$, while 2017 to 2019 at $\$ 233,000$ and 2020 at $\$ 160,00$ are indicated in Ikpoba Hill. These are also reflected in a Trend graph in Figure 1 as follows:

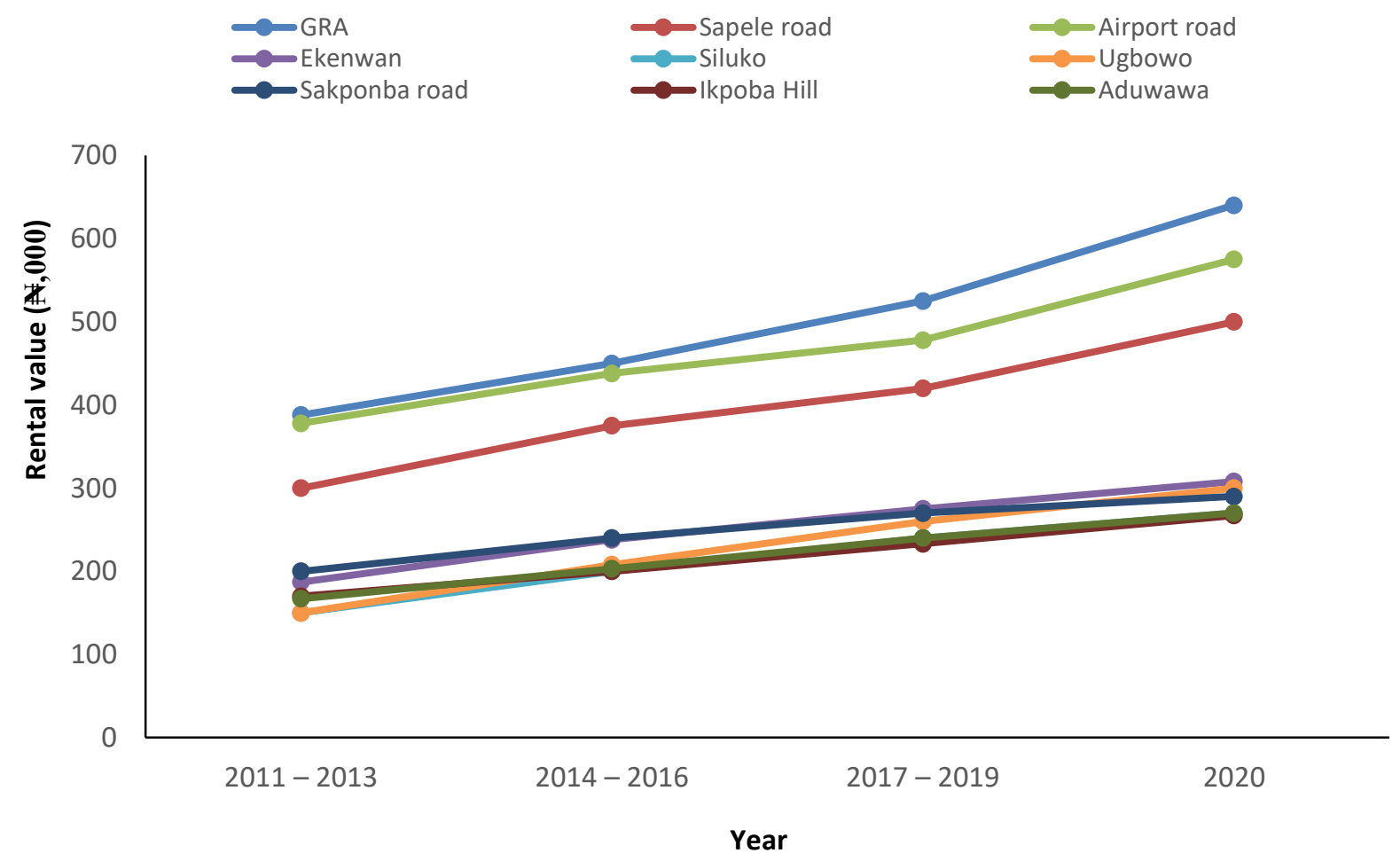

Figure 1:Trend of Rental Values of Bungalows in the Selected Areas of Benin City 
Trend Analysis and Model of Rental Values of Bungalows in the Selected Areas of Benin City Table 2 to Table 9 present the results of the Trend analysis of the rental values of Bungalows in the respective selected areas of Benin from different intervals between 2011 and 2020, with their corresponding Trend Models indicated. The Model formula is analyzed as follows:

$$
\text { Model: } \quad \mathbf{Y}=\mathbf{a}+\mathbf{b t}
$$

Where: $\quad Y=$ the Dependent variable (Rental value to be projected)

$a=$ the intercept (the value of $Y$ - Rental value when $t=0$, that is 2011)

$\mathrm{b}=$ the slope of the line (of Rental value)

$\mathrm{t}=$ the explanatory variable (Period- Year to be projected)

Table 2: $\quad$ Trend Analysis of Rental Values of Bungalows in GRA

\section{Coefficients $^{\mathrm{a}}$}

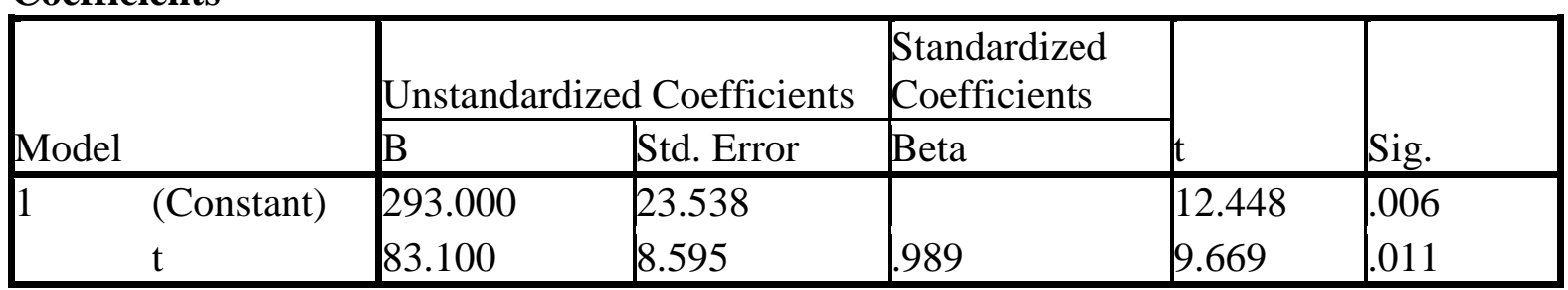

a. Dependent Variable: GRA

b. Predictors: (Constant), $\mathrm{t}$

Model for GRA: $\quad Y=\$ 293,000+\$ 83,100 t$

Table 3: $\quad$ Trend Analysis of Rental Values of Bungalows in Sapele Road Coefficients ${ }^{\mathbf{a}}$

\begin{tabular}{|c|c|c|c|c|c|c|}
\hline \multirow{2}{*}{\multicolumn{2}{|c|}{ Model }} & Unstand: & d Coefficients & \begin{tabular}{|l} 
Standardized \\
Coefficients
\end{tabular} & \multirow[b]{2}{*}{ t } & \multirow[b]{2}{*}{ Sig. } \\
\hline & & $\mathrm{B}$ & Std. Error & Beta & & \\
\hline 1 & $\begin{array}{l}\text { (Constant) } \\
\mathrm{t}\end{array}$ & $\begin{array}{l}237.500 \\
64.500\end{array}$ & $\begin{array}{l}12.772 \\
4.664\end{array}$ & 995 & $\begin{array}{l}18.595 \\
13.830\end{array}$ & $\begin{array}{l}.003 \\
.005\end{array}$ \\
\hline
\end{tabular}

a. $\quad$ Dependent Variable: Sapele Road

b. Predictors: (Constant), $\mathrm{t}$

Model for Sapele Road: $\quad Y=\$ 237,500+\$ 64,500 t$

Table 4: $\quad$ Trend Analysis of Rental Values of Bungalows in Airport Road Coefficients $^{\mathrm{a}}$

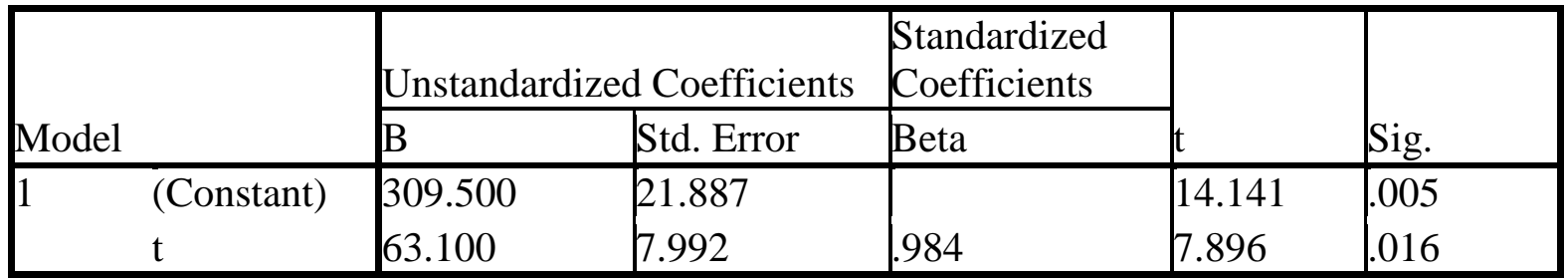

a. Dependent Variable: Airport Road

b. Predictors: (Constant), $\mathrm{t}$

Model for Airport Road: $\quad Y=\$ 309,500+\$ 63,100 t$ 
Table 5: $\quad$ Trend Analysis of Rental Values of Bungalows in Ekenwan Coefficients $^{\mathbf{a}}$

\begin{tabular}{|c|c|c|c|c|c|c|}
\hline \multirow{2}{*}{\multicolumn{2}{|c|}{ Model }} & Unstand: & d Coefficients & $\begin{array}{l}\text { Standardized } \\
\text { Coefficients }\end{array}$ & \multirow[b]{2}{*}{$T$} & \multirow[b]{2}{*}{ Sig. } \\
\hline & & $B$ & Std. Error & Beta & & \\
\hline 1 & $\begin{array}{l}\text { (Constant) } \\
\mathrm{t}\end{array}$ & $\begin{array}{l}152.000 \\
40.000\end{array}$ & $\begin{array}{l}8.031 \\
2.933\end{array}$ & .995 & $\begin{array}{l}18.926 \\
13.640\end{array}$ & $\begin{array}{l}.003 \\
.005\end{array}$ \\
\hline
\end{tabular}

a. Dependent Variable: Ekenwan

b. Predictors: (Constant), $\mathrm{t}$

Model for Ekenwan: $Y=\$ 152,000+\$ 40,000 t$

Table 6: $\quad$ Trend Analysis of Rental Values of Bungalows in Siluko Coefficients $^{\mathbf{a}}$

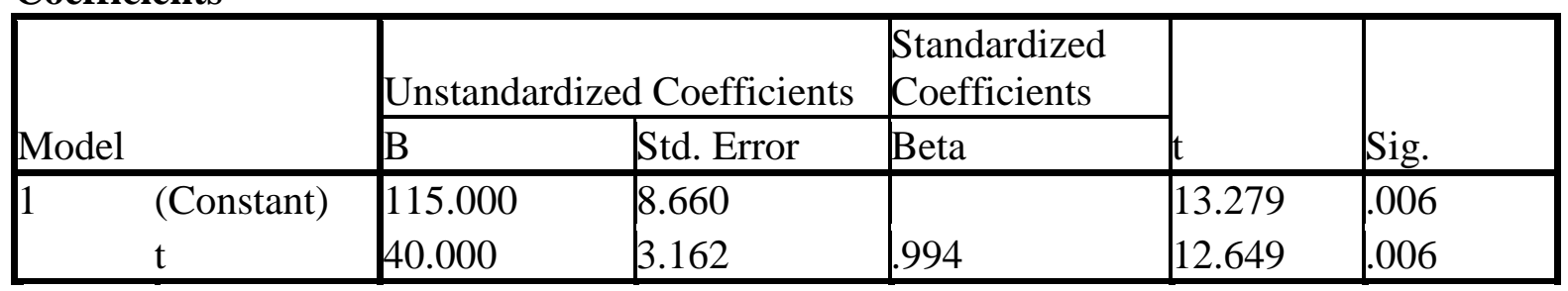

a. Dependent Variable: Siluko

b. Predictors: (Constant), $\mathrm{t}$

Model for Siluko: $\quad Y=\$ 115,000+\$ 40,000 t$

Table 7: $\quad$ Trend Analysis of Rental Values of Bungalows in Ugbowo Coefficients $^{\mathrm{a}}$

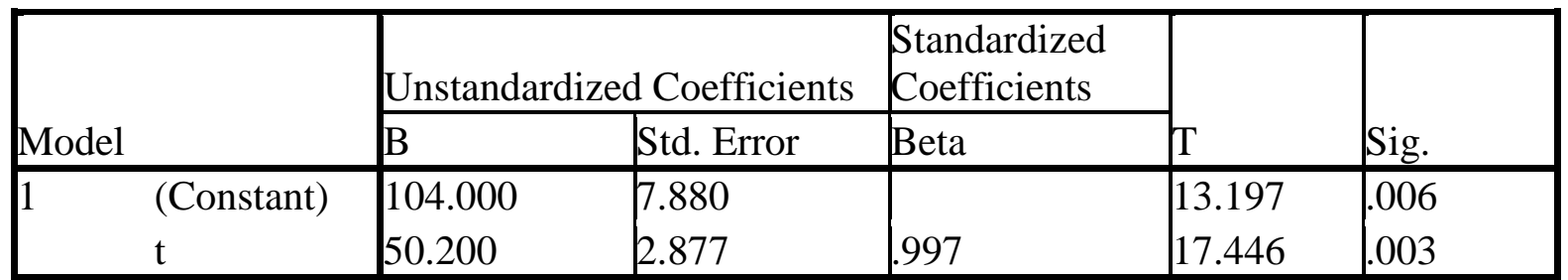

a. Dependent Variable: Ugbowo

b. Predictors: (Constant), $\mathrm{t}$

Model for Ugbowo: $Y=\$ 104,000+\$ 50,200 t$

Table 8: $\quad$ Trend Analysis of Rental Values of Bungalows in Sakponba Road Coefficients $^{\mathbf{a}}$

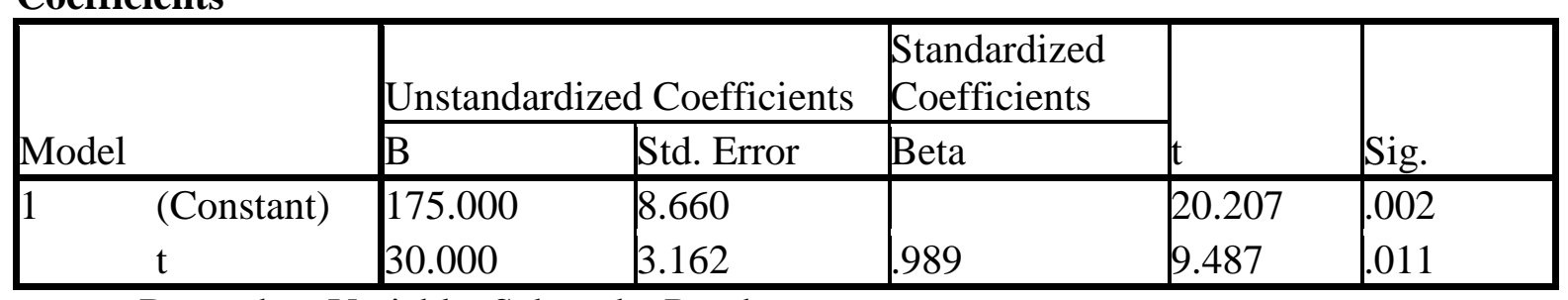

a. Dependent Variable: Sakponba Road

b. Predictors: (Constant), $\mathrm{t}$

Model for Sakponba Road: $Y=\$ 175,000+\$ 30,000 t$ 
Table 9: $\quad$ Trend Analysis of Rental Values of Bungalows in Ikpoba Hill Coefficients $^{\mathbf{a}}$

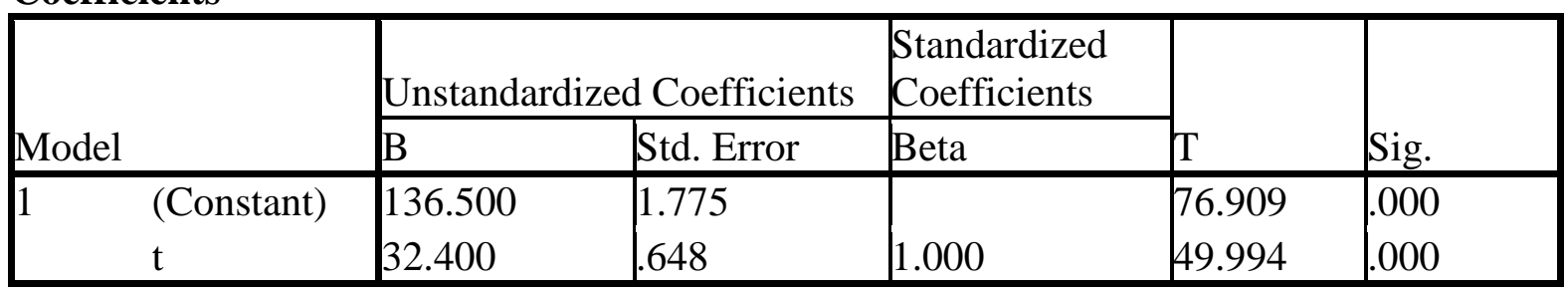

a. Dependent Variable: Ikpoba Hill

b. Predictors: (Constant), $\mathrm{t}$

Model for Ikpoba Hill: $\quad Y=\$ 136,500+\$ 32,400 t$

Table 10: Trend Analysis of Rental Values of Bungalows in Aduwawa Coefficients $^{\mathbf{a}}$

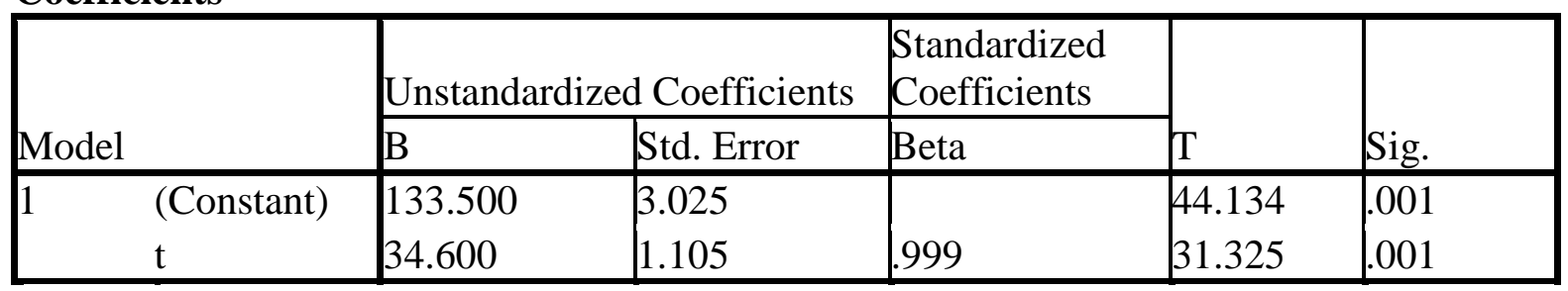

a. Dependent Variable: Aduwawa

b. Predictors: (Constant), $\mathrm{t}$

Model for Aduwawa: $\quad \mathrm{Y}=\$ 133,500+\$ 34,600 \mathrm{t}$

From Table 2 to Table 10 reflecting in their respective Trend models, the highest rental value intercept of $\$ 309,500$ at year 0 (2011) is indicated in Airport road with highest rental value slope line of $\$ 83,100$ in GRA, while the lowest rental intercept of $\$ 104,000$ is indicated in Ugbowo with lowest rental value slope line of $\$ 30,000$ in Sakponba road.

\section{Test of Hypothesis}

H01: There is no significant variation in the rental values of Bungalow residential properties within the selected areas (GRA, Sapele road, Airport road, Ekenwan, Siluko, Ugbowo, Sakponba road, Ikpoba Hill and Aduwawa) of the study area from 2011 to 2020.

The data in Table 1 were used to test the Hypothesis above, using One-way Analysis of Variance (ANOVA), which is carried out to test the variation between the mean rental values of Bungalows within each of the selected areas from 2011 to 2020 at three yearly intervals. The analysis in Table 11 is carried out to determine whether there is a significant variation between the rental values of Bungalows within the nine (9) selected areas in the study area as follows: 
Print ISSN: 2053-4086(Print),

Online ISSN: 2053-4094(Online)

Table 11: Oneway ANOVA for Rental Values of Bungalows in the Selected Areas ANOVA

\begin{tabular}{|c|c|c|c|c|c|c|}
\hline & & Sum of Squares & $\mathrm{df}$ & Mean Square & $F$ & Sig. \\
\hline GRA & $\begin{array}{l}\text { Regression } \\
\text { Residual } \\
\text { Total }\end{array}$ & $\begin{array}{l}34528.050 \\
738.700 \\
35266.750\end{array}$ & $\begin{array}{l}1 \\
2 \\
3\end{array}$ & $\begin{array}{l}34528.050 \\
369.350\end{array}$ & 93.483 & $.011^{\mathrm{b}}$ \\
\hline Sapele Road & $\begin{array}{l}\text { Regression } \\
\text { Residual } \\
\text { Total }\end{array}$ & $\begin{array}{l}20801.250 \\
217.500 \\
21018.750\end{array}$ & $\begin{array}{l}1 \\
2 \\
3\end{array}$ & \begin{tabular}{|l}
20801.250 \\
108.750
\end{tabular} & 191.276 & $.005^{\mathrm{b}}$ \\
\hline Airport Road & Regression & 19908.050 & 1 & 19908.050 & 62.339 & $.016^{\mathrm{b}}$ \\
\hline & $\begin{array}{l}\text { Residual } \\
\text { Total }\end{array}$ & $\begin{array}{l}638.700 \\
20546.750\end{array}$ & 2 & 319.350 & & \\
\hline Ekenwan & $\begin{array}{l}\text { Regression } \\
\text { Residual }\end{array}$ & $\begin{array}{l}8000.000 \\
86.000\end{array}$ & $\begin{array}{l}1 \\
2\end{array}$ & $\begin{array}{l}8000.000 \\
43.000\end{array}$ & 186.047 & $.005^{\mathrm{b}}$ \\
\hline & Total & 8086.000 & 3 & & & \\
\hline Siluko & Regression & 8000.000 & 1 & 8000.000 & 160.000 & $.006^{\mathrm{b}}$ \\
\hline & $\begin{array}{l}\text { Residual } \\
\text { Total }\end{array}$ & $\begin{array}{l}100.000 \\
8100.000\end{array}$ & 2 & 50.000 & & \\
\hline Ugbowo & $\begin{array}{l}\text { Regression } \\
\text { Residual } \\
\text { Total }\end{array}$ & $\begin{array}{l}12600.200 \\
82.800 \\
12683.000\end{array}$ & $\begin{array}{l}1 \\
2 \\
3\end{array}$ & $\begin{array}{l}12600.200 \\
41.400\end{array}$ & 304.353 & $.003^{\mathrm{b}}$ \\
\hline Sakponba & Regression & 4500.000 & 1 & 4500.000 & 90.000 & $.011^{\mathrm{b}}$ \\
\hline & $\begin{array}{l}\text { Residual } \\
\text { Total }\end{array}$ & $\begin{array}{l}100.000 \\
4600.000\end{array}$ & 3 & 50.000 & & \\
\hline Ikpoba Hill & $\begin{array}{l}\text { Regression } \\
\text { Residual } \\
\text { Total }\end{array}$ & \begin{tabular}{|l|}
5248.800 \\
4.200 \\
5253.000
\end{tabular} & $\begin{array}{l}1 \\
2 \\
3\end{array}$ & $\begin{array}{l}5248.800 \\
2.100\end{array}$ & 2499.429 & $.000^{\mathrm{b}}$ \\
\hline Aduwawa & Regression & 5985.800 & 1 & 5985.800 & 981.279 & $.001^{\mathrm{b}}$ \\
\hline & $\begin{array}{l}\text { Residual } \\
\text { Total }\end{array}$ & $\mid \begin{array}{l}12.200 \\
5998.000\end{array}$ & 3 & 6.100 & & \\
\hline
\end{tabular}

The null hypothesis states that there is no significant variation in the rental values of Bungalows within Benin City, From the ANOVA result presented above; we strongly reject the null hypothesis because the p-values calculated for GRA is 0.011, Sapele road is 0.005, Airport road is 0.016, Ekenwan is 0.005, Siluko is 0.006, Ugbowo is 0.003, Sakponba road is 0.011, Ikpoba Hill is 0.000 and Aduwawa is 0.001 , which are all respectively less than 0.05 . We therefore make our conclusion that there is statistically significant variation in the rental values of Bungalows in the selected areas.

\section{FINDINGS AND CONCLUSION}

\section{Findings}

From the study analysis, it is revealed that the Rental values of Bungalow residential property types indicated various trends within the selected areas in Benin City; GRA, Sapele road, Airport road, Ekenwan, Siluko, Ugbowo, Sakponba road, Ikpoba Hill and Aduwawa. Figure 1 presented the graphical trend of rental values in the selected areas within the period intervals, while Table 2 to Table 
10 presented the analyses of the trends resulting in the corresponding model of rental value growth over the period with rental value in base year (2011) highest in Airport road and lowest in Ugbowo, and unit change in rental value per year highest in GRA and lowest in Sokponba road.

Furthermore, the analysis carried out in Table 11 revealed that there is variation in Rental values of Bungalows within each of the selected areas in Benin with the One-way ANOVA test conducted producing p-values which are all lower than 0.05. Therefore, we rejected the null Hypothesis which states that there is no significant variation in the rental values of Bungalow residential properties within the selected areas of the study area, and accepted the alternative which states that there is significant variation in the rental values of Bungalow residential properties within the selected areas.

The variations in rental values of such residential properties in the selected areas were objectively determined by some factors which comprised majorly of; the sized of the building and its compound, level of facilities available, the neighbourhood characteristics, market trend among other factors identified by respondents.

\section{Conclusion}

The study analyzed and compared the trends of Rental values of Bungalow residential properties between 2011 and 2020 considering an ideal conventional rent review period of 3 yearly intervals, in selected areas in Benin City, and thus concluded that there is variation in rental values of Bungalows within each of the selected areas. These variations in rental values were attributed to be determined by some factors such as; the sized of the building and its compound, level of facilities available, the neighbourhood characteristics, etc.

\section{Recommendations}

From the conclusion of the study, it is recommended that investment in Bungalow residential properties in Benin City produce good trend of rental values as there is general relative growth over time, however, Airport road and GRA indicate best potential for investors. Investors should also ensure that their Bungalow developments should be of good size with adequate facilities and in appealing neighbourhood to command the best rental benefits.

\section{REFERENCES}

Egolum, C. C. (2002). Fundamentals of estate management. Lagos, Nigeria: Snaap press.

Ekenta, C. (2015). Analysis of rental value trend : (The case of residential properties in d/line, Port Harcourt). Asian Academic Research Journal of Social Sciences and Humanities, Vol 2(4), 110

Emoh, F. I. (2004). Real Property Investment and Management. Awka: Christain International Co. Ltd.

Kuye, O. (2003). Principles and Practice of Property Valuation. Lagos: Climax Communications Ltd.

Kuye, O. G. (2009). Property valuation techniques (A practical approach). Lagos, Nigeria: Climax communication

Kuye, O. G. (2011). Estate practice ( $2^{\text {nd }}$ ed.). Lagos, Nigeria: Adro Dadar Heritage. 
Ogunba, O. A. (2013). Principles and practice of property valuation in Nigeria. Ibadan, Nigeria: Atlantis books,

Omotoso, J. B. (2002). Synoptic Meteorology: Pathway to Seasonal Rainfall Prediction for Sustainable Agriculture and Effective Water Resource Management in West Africa but Nigeria in Particular. Journal of the Nigerian Meterological Society, 3(1):81-89.

Pallant, J. (2011). SPSS survival manual $\left(4^{\text {th }}\right.$ ed.). New South Wales, Australia: Allen \& Unwin.

Singleton R. A., \& Straits B. C. (2009).. Approaches to social research. New York: Oxford University Press; (Google Scholar). Retrieved $2^{\text {nd }}$ feb, 2021

The Nigeria Valuation Standards (2019). The Green Book. Estate Surveyors and Valuers Registration Board of Nigeria (ESVARBON), Lagos, Nigeria

Udechukwu, C. E. (2006). Principles of valuation. Lagos, Nigeria: Treem.

United Nation's (UN) - World Population Prospects (2021). Benin City, Nigeria Metro Area Population 1950-2021. https://www.macrotrends.net/cities/21981/benin-city/population. Retrieved 2021-11-20 